\title{
THE RESPONSES OF NET ECOSYSTEM PRODUCTION TO CLIMATE CHANGE: A MODELLING STUDY TO IDENTIFY THE SINK AND SOURCE OF CARBON REGIONS AT THE PAN- EUROPEAN SCALE
}

\author{
SAKALLI, A. \\ Department of Industrial Engineering, Faculty of Engineering and Natural Sciences, \\ Iskenderun Technical University, Merkez Kampus, TR-31230 Iskenderun (Hatay), Turkey \\ (e-mail: abdulla.sakalli@iste.edu.tr; phone: +90-536-506-9191) \\ (Received 25 $5^{\text {th }}$ Dec 2019; accepted $25^{\text {th }}$ May 2020)
}

\begin{abstract}
Identifying sinks or sources of $\mathrm{CO}_{2}$ in the terrestrial biosphere has become an important topic in the last decades. Net Ecosystem Production (NEP) is one of the most used parameters for the understanding and visualization of change in a sink or source of $\mathrm{CO}_{2}$ under consideration of climate change, and transient $\mathrm{CO}_{2}$ in modelling and in-situ studies. In this study, NEP was obtained by running the Community Land Model (CLM version 4.5) with $25 \times 25 \mathrm{~km}$ high spatial resolution between 1971 and 2100. It was focused on analyzing the NEP for two periods (i.e. 1971-2000 as past period and 20712100 as future period). Within the study, the model was integrated with used bias corrected six climate parameters and transient $\mathrm{CO}_{2}$ up to 2100 . Validation of the model results showed a quite good correlation (ca. 77\%) with observed NEP data. NEP will have an increase up to ca. 118\% on an average, at panEuropean scale in 2100. Although carbon accumulation in terrestrial biosphere will increase in most of the areas of the pan-European region, the accumulation will decrease in Eastern Europe. These results particularly highlight the spatial and temporal distribution of NEP, and also a significant increase of NEP in the terrestrial biosphere under climate change and transient $\mathrm{CO}_{2}$ at pan-Europe scale.
\end{abstract}

Keywords: ecosystem exchange, biogeochemistry, carbon uptake, dynamic modelling, earth system modelling, operational research, industrial engineering, Industry 4.0

\section{Introduction}

Modelling studies are quite essential research activities for investigations related to changes in the sensitivities of climate, depending on biogeochemical processes in terrestrial biosphere. In the last century, the significance of anthropogenic greenhouse gas emission due to industrial development (from industry 1.0 to Industry 4.0) and climate change effects on carbon cycle in terrestrial biosphere has been increasing, and various researches have been conducted on it. In this topic, Net Ecosystem Production has high importance for clarifying the change in organic carbon storage capacity of terrestrial biosphere. The oldest known modern definition of NEP was published in the late 60s (Woodwell and Whitthaker, 1968). They defined the NEP as the difference between Gross Primary Production (GPP) and ecosystem respiration. NEP is defined as the import of organic carbon in or out of the ecosystems, i.e., increase or decrease of organic carbon via carbon storage in vegetation, sediments, and soils, or the carbon lost through land-use change, fire, respiration, and oxidation, regulate carbon budget between the atmosphere and terrestrial biosphere (Lovett et al., 2006; Hinojo-Hinojo et al., 2019). Ecosystems with $N E P>0$ are considered as carbon sink ecosystems where carbon binding into the biomass or other organic and non-organic materials is greater than carbon emission (Esser et al., 2011). Also, ecosystems with NEP $<0$ are considered as carbon source ecosystems where the carbon emission processes greater than carbon storage. A measure of Net Ecosystem Production is of great interest for 
investigations to be made of carbon balance between atmosphere and terrestrial biosphere. There are various factors which can affect the NEP in different ecosystems in a timescale, from seconds to millennium (Randerson et al., 2002; Chen et al., 2019; Wong et al., 2020). GPP and ecosystem respiration can have an influence in a timescale from seconds to years, fire and leaching processes from year to decades, and soil formation and erosion from decades to millennium. Esser et al. (2011) also referred to the meaning of studying and analyzing the missing sink of carbon onto the Earth ecosystems during the last century. Their modelling experiments pointed to globally $\sim 160 \mathrm{Pg} \mathrm{C}$ missing sink, and it is highly affected by the available nitrogen in terrestrial biosphere during long-term simulations. Climate variability, nitrogen deposition, and plant growth by elevated atmospheric $\mathrm{CO}_{2}$ are often considered to be the main processes (i.e., in ecological terms, consequences for $\mathrm{C}$ fluxes), which have direct relationships with NEP in terrestrial biosphere (Jarvis, 1995; Campbell et al., 2004; Han et al., 2019). There are numerous methods to investigate the effects of atmospheric change on biogeochemical cycles, e.g., carbon exchange between atmosphere and terrestrial biosphere (Turner et al., 2007; Jiang et al., 2013; Liu et al., 2015; Seidensticker et al., 2019; Schulze et al., 2019). Erickson et al. (2013) aimed to measure both direct and indirect effects of elevated ambient $\mathrm{CO}_{2}$ on NEP using an open top chamber method for eighteen years experiments. Under doubled atmospheric $\mathrm{CO}_{2}$, the NEP had an increase of about $20-25 \%$ in study areas and biomes. NEP is highly depended on plant functional types in terrestrial ecosystem. For instance, needleleaf evergreen forests exchange about six times more carbon than broadleafed deciduous forest (Potter et al., 1993). Grasslands and cultivated crop lands have lower NEP than temperate forests in the northern hemisphere. In an in-situ study of temperate pine plantation, NEP showed a strong dependence on temperature, light regime, and water vapor pressure deficit (Arain and Restrepo-Coupe, 2005; Fernandez-Martinez et al., 2019). A modelling study about NEP under climate change on pan-European scale can indicate the regions of carbon sink or source, and the changes in the sink to source or vice versa. Although there are various studies about carbon sinks/sources by regions or biomes at a global scale, there is little information about carbon sinks/sources in pan-European biomes (Pan et al., 2011; Nabuurs et al., 2013; Fernandez-Martinez et al., 2019). Nabuurs et al. (2013) and Pittau et al. (2019) found valuable signs for saturation of carbon sink in European forests. They observed three types of warnings (i.e., decrease in stem diameter, increase in land-use change, and increase in natural disturbances), which features a decrease in the sink/source ratio in European forests. However, there are still open questions about the behavior of the source and sink of the carbon regions in pan-European forests under climate changes in the future.

In this study, the main aim is to investigate the alteration in potentiality of carbon sink or source of the pan-European forests under climate change of 2100.

\section{Materials and methods}

For an estimation of the net ecosystem production, the Community Land Model version 4.5 (Oleson et al., 2013) was established at a pan-European scale on $25 \times 25 \mathrm{~km}$ grid resolution. The model was run with bias corrected climate data for 800 years, in accelerated mode, to get the main carbon pools of the terrestrial biosphere in a steady state. The methodology of accelerated mode and steady state run (spin-up) was published by Koven et al. (2013). After spinning up of the model, it was run with 
required climate data from 1970 to 2100 . Two 30 year-periods (1971-2000 and 20702100) were taken into account for an investigation of the change of the NEP in the past observed period (1971-2000) since we have bias corrected climate data for this time range and future projected period (2071-2100) at a pan-European scale. To force the model with required climate, six climate parameters (Table 1) from the CSC-REMO regional climate model (RCM), driven by MPI-ESM-LR-r1 General Circulation Model (GCM) were used for this modelling study. All climate parameters were bias corrected through a method by Jacob et al. (2013). The conditions of the Representative Concentration Pathway 4.5 (RCM 4.5) scenario are the most plausible conditions that we can reach it under climate change at the end of this century (Jacob et al., 2013). Therefore, we decided to use the RCM model, which was implemented under consideration with regards to the RCP4.5 scenario for prediction of the climate parameter from 2005 to 2100 . The CLM model was forced with transient $\mathrm{CO}_{2}$ for this modelling study. The transient data for $\mathrm{CO}_{2}$ were obtained from IIASA RCP database (http://tntcat.iiasa.ac.at/RcpDb) from 1850 to 2100. The $\mathrm{CO}_{2}$ data was historical data for the time range 1850-2004, and the projected data for RCP4.5 scenario was from 2005 to 2100 .

Table 1. The used climate variable for atmospheric forcing of CLM4.5 model

\begin{tabular}{c|c}
\hline Code & Variable name as daily mean value (unit) \\
\hline $\operatorname{tas}$ & Surface temperature at $2 \mathrm{~m}\left({ }^{\circ} \mathrm{C}\right)$ \\
\hline $\mathrm{pr}$ & Sum of precipitation $(\mathrm{mm})$ \\
\hline rlds & Surface downwelling longwave radiation $\left(\frac{\mathrm{W}}{\mathrm{m}^{2}}\right)$ \\
\hline rsds & Surface downwelling shortwave radiation $\left(\frac{\mathrm{W}}{\mathrm{m} 2}\right)$ \\
\hline huss & Near surface specific humidity $\left(\frac{\mathrm{kg}}{\mathrm{kg}}\right)$ \\
\hline sfcWind & Near surface wind speed $\left(\frac{\mathrm{m}}{\mathrm{sm}}\right)$ \\
\hline
\end{tabular}

The CLM4.5 was configured with CLM4.5-CN (i.e., open carbon-nitrogen interaction, no fire, land-use from 2000, and no land-use) component set for enabling full carbon-nitrogen interaction in the model.

The NEP is defined as in Equation 1 in the model.

$$
N E P=G P P-\left(R_{p}+R_{h}+R_{d}\right)
$$

where GPP is gross primary production, $\mathrm{R}_{\mathrm{p}}, \mathrm{R}_{\mathrm{h}}, \mathrm{R}_{\mathrm{d}}$ are respiration by plants, heterotrophs, and decomposers, respectively. For statistical analysis, SPSS statistic software (version 23) was used to define the multiple linear regressions between NEP and it used six climate parameters. For this statistical analysis, the average data of panEuropean domain were extracted for the time between 1971 and 2100. A total of 130 data sample (1971-2100) for all six climate and NEP were used in the regression analysis.

To validate the results of the model for NEP, a collection of NEP observation data from the research article Arain and Restrepo-Coupe (2005) was used. In the data 
collection, there was NEP data from 20 study sites, located in different climate zones on the Earth (Fig. 1). Eight locations, situated within the domain of the CLM4.5 in this study, were selected for the validation of the model. The observed NEP data were obtained in different time scales. Therefore, the results of the model were selected for the same time range and locations as the validation processes.

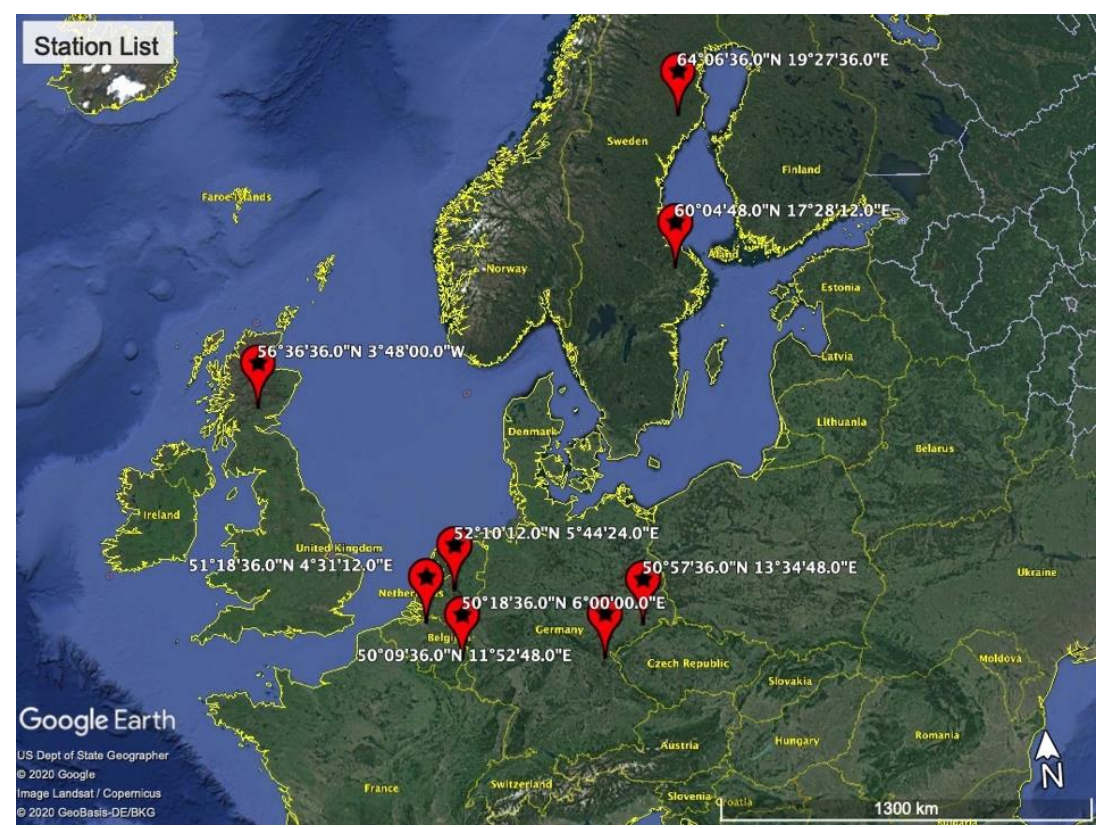

Figure 1. Station locations with the observed NEP data

For the correlation analysis, the index of agreement method was used (Willmott, 1981). The index of agreement method is a standardized measure of the degree of model prediction errors and varies from 0 to 1 . The value of 1 indicates a very well agreement of the model results with the observation.

$$
d=1-\frac{\sum_{i=1}^{n}\left(o_{i}-P_{i}\right)^{2}}{\sum_{i=1}^{n}\left(\left|p_{i}-\sigma\right|+\left|o_{i}-\sigma\right|\right)^{2}}, \quad 0 \leq d \leq 1
$$

\section{Results and discussion}

Temporal progression of NEP from 1971 to 2100 is plotted in Figure 2. It is clearly seen that there is, on an average, an upward tendency in the change of NEP from being carbon source to carbon sink in pan-European regions (Fig. 2). In the figure, the trendline show that the NEP has, in average, an increase about $65 \frac{g C}{m^{2} y r}$, which is equal to ca. $118 \%$ increase from 1971 to 2100 . In the same figure, a remarkable point is that the inter-annual amplitude starts to considerably increase after 2050 up to 2100 . The increase of $\mathrm{CO}_{2}$ in the atmosphere, for different RCP scenarios, is shown in Figure 3. The atmospheric $\mathrm{CO}_{2}$ concentration increases within the RCP4.5 emission scenario from 2000 up to 2080. According to the RCP4.5 scenario, the atmospheric $\mathrm{CO}_{2}$ concentration has a rapid increase between 2030 and 2060, however, NEP mostly has minimal amplitude, and saturates at a $\mathrm{CO}_{2}$ concentration between 450 and $550 \mathrm{ppm}$ 
during that time range (Fig. 2). That means, an increase in $\mathrm{CO}_{2}$ expedites total ecosystem respiration more than carbon assimilation in terrestrial biosphere at a panEuropean scale. These results match the results of the study about dynamic response of terrestrial biosphere under climate change (Cao and Woodward, 1998).

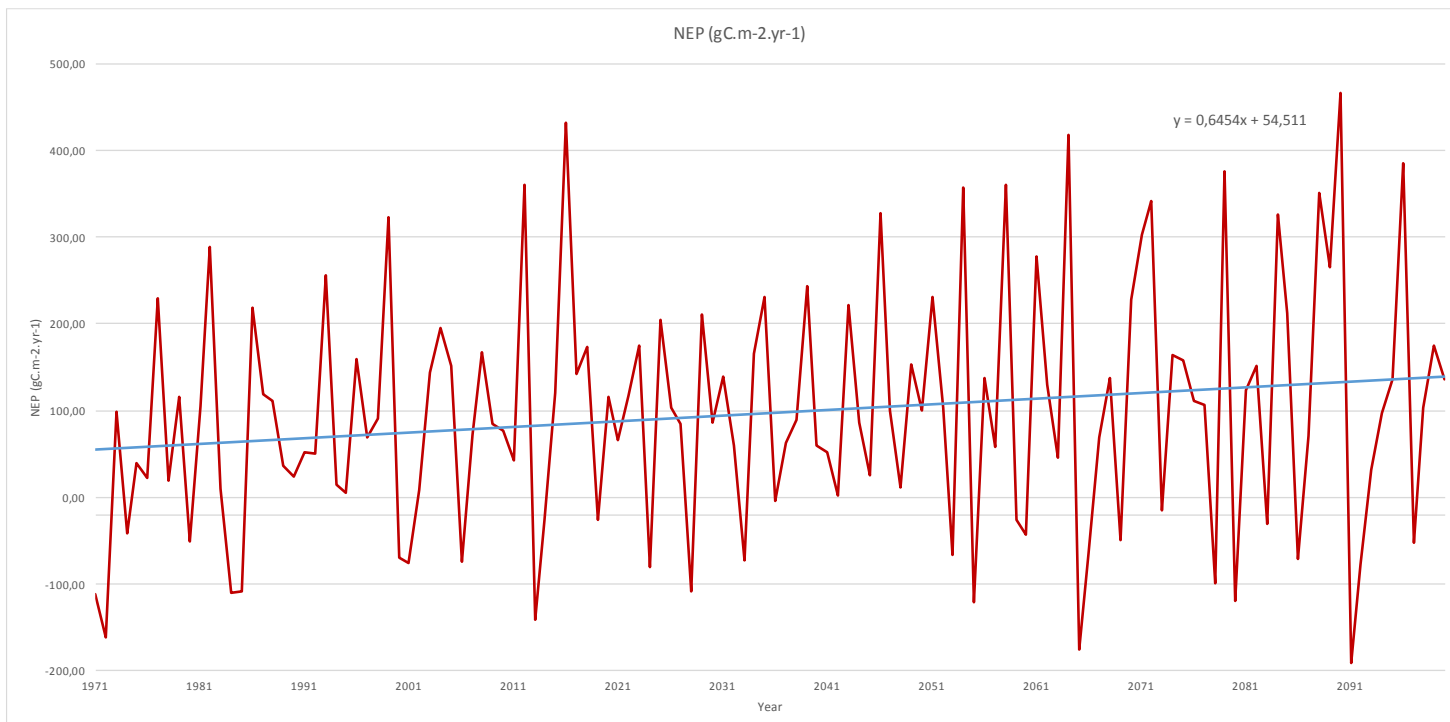

Figure 2. The pan-European average NEP change, which is predicted by CLM4.5 under consideration the RCP4.5 emission scenario from 1971 to 2100

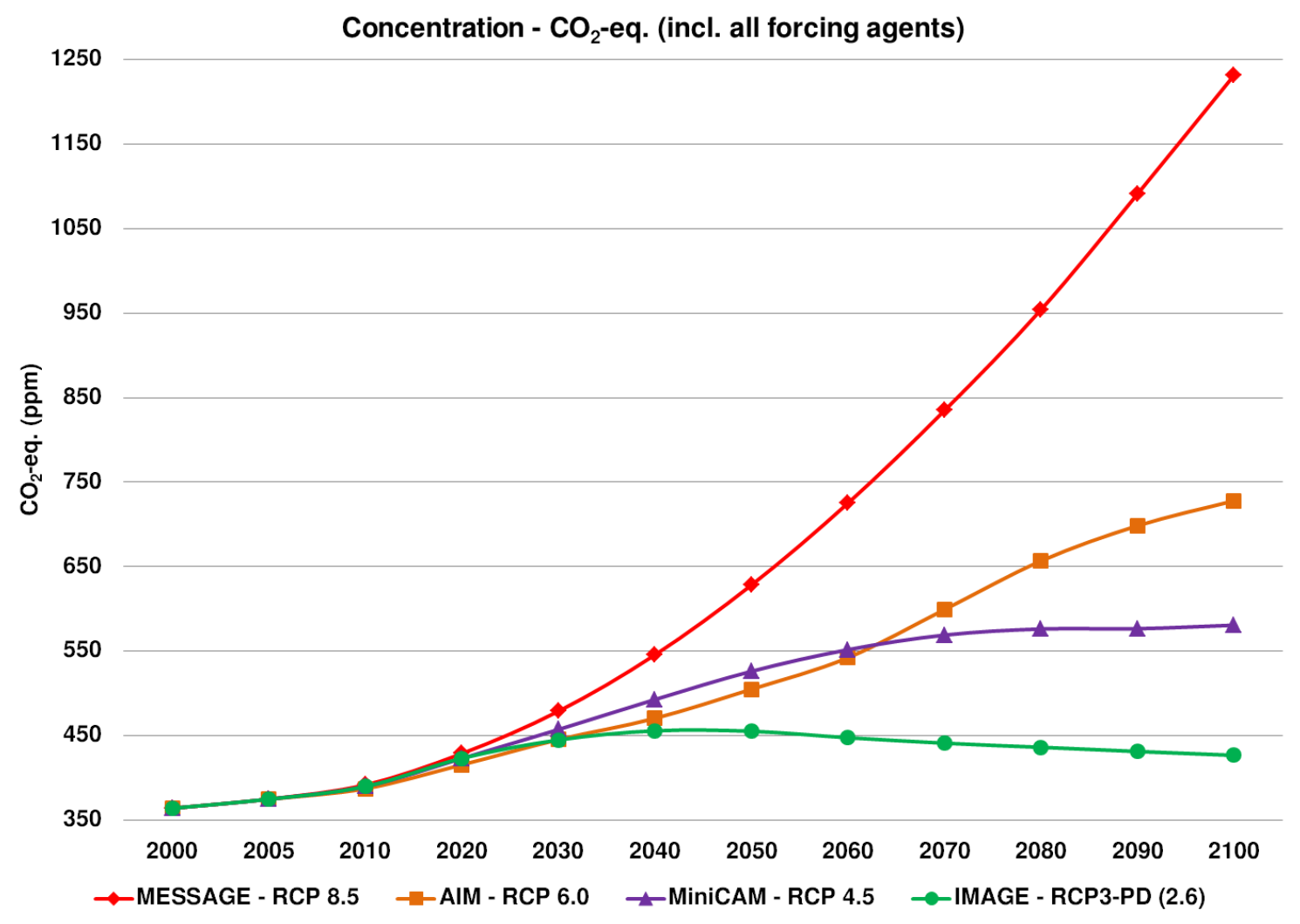

Figure 3. Atmospheric $\mathrm{CO}_{2}$ concentration under different RCP scenarios from 2000 to 2100 
The observed and predicted NEP data are presented with the coordinates of the study sites, the name of the climate zones, and the collection years in Table 2. The NEP results of the model were selected for the same locations of the validation data. In Figure 4, the correlation scatter plot was presented. The amount of the NEP from different study sites were illustrated with different shape and color. The figure shows that there is quite a good correlation $\left(\mathrm{R}^{2}=0.77\right)$ between observed and predicted NEP in the study sites and times. And also, all the points distributed evenly around the linear regression line. The correlation analysis by using the index of agreement (according to $E q .2)$ method indicates also very good result $(\mathrm{d}=0.90)$.

Table 2. The observed and predicted NEP in different climate zones

\begin{tabular}{|c|c|c|c|c|}
\hline Latitude, longitude & Year & Climate zone & NEP Obs. $\left(\frac{g C}{m^{2} y F}\right)$ & NEP CLM4.5 $\left(\frac{g C}{m^{2} W}\right)$ \\
\hline \multirow{5}{*}{$51.31,4.52$} & 1997 & \multirow{5}{*}{ Temperate } & -76 & 80 \\
\hline & 1998 & & -105 & -35 \\
\hline & 1999 & & -130 & -185 \\
\hline & 2000 & & -255 & -330 \\
\hline & 2001 & & 9 & 40 \\
\hline \multirow{4}{*}{$50.31,6.0$} & 1997 & \multirow{4}{*}{ Temperate } & 430 & 391 \\
\hline & 1998 & & 435 & 317 \\
\hline & 1999 & & 760 & 424 \\
\hline & 2000 & & 740 & 372 \\
\hline \multirow{4}{*}{$52.17,5.74$} & 1997 & \multirow{4}{*}{ Temperate } & 323 & 448 \\
\hline & 1998 & & 338 & 261 \\
\hline & 1999 & & 230 & 184 \\
\hline & 2000 & & 344 & 151 \\
\hline \multirow{3}{*}{$60.08,17.47$} & 1995 & \multirow{3}{*}{ Boreal } & -90 & -59 \\
\hline & 1996 & & 5 & 48 \\
\hline & 1997 & & -80 & -28 \\
\hline \multirow{2}{*}{$64.11,19.46$} & 1997 & \multirow{2}{*}{ Boreal } & 173 & 112 \\
\hline & 1998 & & -53 & -17 \\
\hline \multirow{2}{*}{$56.61,-3.8$} & 1997 & \multirow{2}{*}{ Temperate } & 670 & 326 \\
\hline & 1998 & & 570 & 240 \\
\hline \multirow{5}{*}{$50.96,13.58$} & 1996 & \multirow{5}{*}{ Temperate } & 330 & 430 \\
\hline & 1997 & & 480 & 376 \\
\hline & 1998 & & 540 & 273 \\
\hline & 1999 & & 628 & 565 \\
\hline & 2000 & & 648 & 316 \\
\hline \multirow{3}{*}{$50.16,11.88$} & 1997 & \multirow{3}{*}{ Temperate } & 77 & 13 \\
\hline & 1998 & & -9 & -35 \\
\hline & 1999 & & 76 & 164 \\
\hline
\end{tabular}




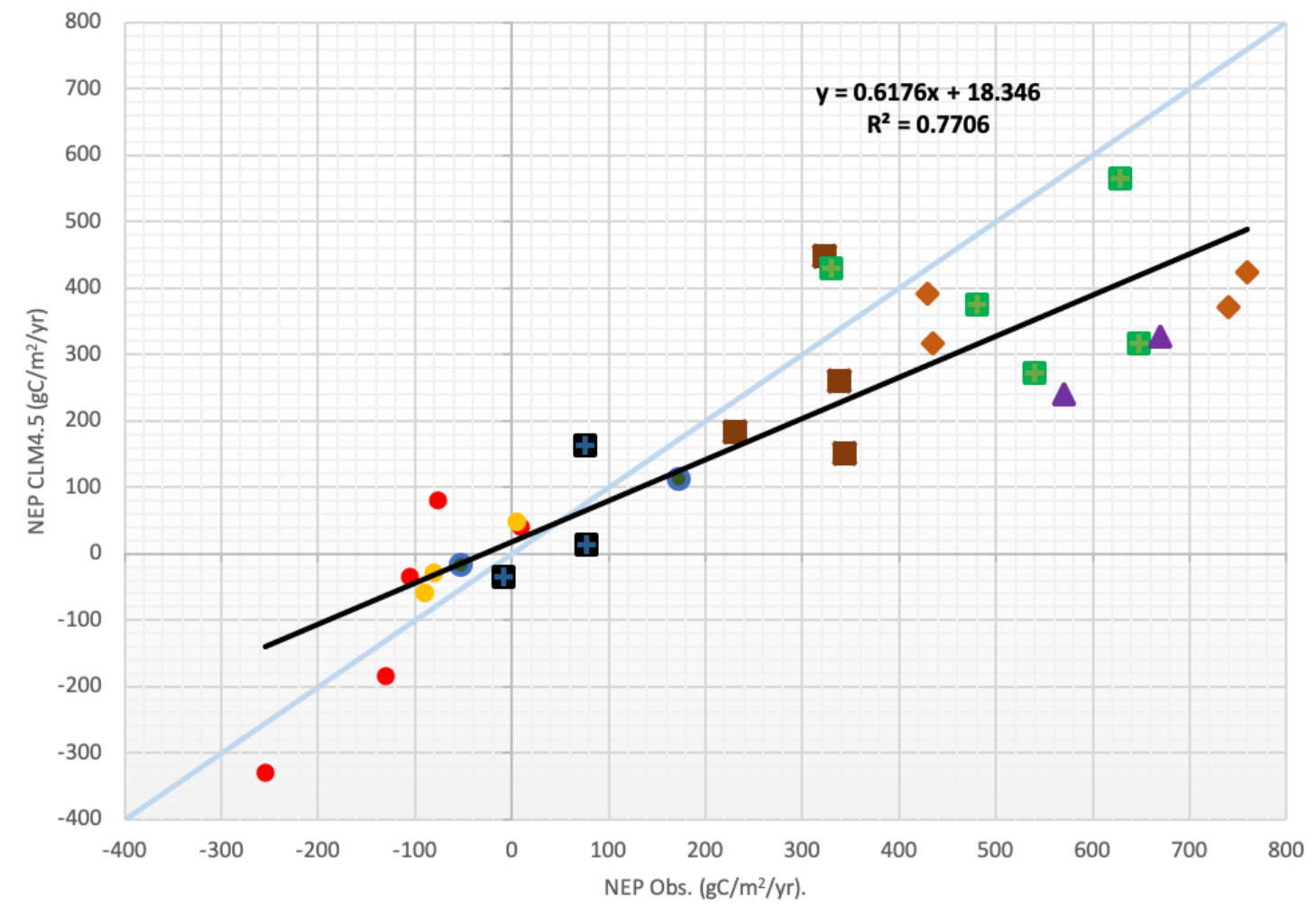

Figure 4. The correlation between observed and predicted NEP in eight study areas, which are located in different climate zones in Europe. The colors indicate each study site location

In this study it is also aimed to find out whether there is a correlation between used six climate variables, atmospheric $\mathrm{CO}_{2}$ concentration and NEP. The multi regression analysis shows that there is no significant correlation between the climate variables and atmospheric $\mathrm{CO}_{2}$ in pan-European scale. The considered six climate variable and atmospheric $\mathrm{CO}_{2}$ concentration explains ca. $7 \%$ of variation in NEP of this study, from 1971 to 2100 (Table 1). The statistical analysis shows no direct correlation between any single climate variable, $\mathrm{CO}_{2}$ and NEP (Table 3). In similar early studies, the correlation between NEP and climate variables (i.e., temperature and precipitation) was also analyzed in different biome types (Law et al., 2002; Luyssaert et al., 2007). They published similar correlation results between the used climate variables and NEP (i.e., no correlation). On the other hand, Magnani et al. (2007) pointed out that the NEP is strongly related to nitrogen deposition, and not to the annual average temperature in both temperate and boreal forests. The inter-annual variability of NEP was well studied in different biome types (Nayak et al., 2015; Baldocchi et al., 2018; Yang et al., 2019). They concluded the study noting that NEP is highly dependent on biome types as well as on annual climatology across the country. Such results refer to study the effects of PFTs on NEP at a pan-European scale.

In Figure 5, the 30 years average of NEP on pan-European scale is shown. Most of the regions in pan-Europe are sink for carbon, however, some regions, especially in the central and southern Europe, are sources of carbon (Fig. 5). In the source regions, the vegetation types are mainly grasslands and cultivated croplands. Here, the total respiration (i.e., plant, heterotrophs, decomposer) is more dominant than the carbon uptake by GPP (according to the Eq. 1). As it is expected, the sink regions of carbon are 
mainly in the eastern and southeastern parts of Europe, where the temperate deciduous broadleafed forests are the dominant biome types (Fig. 5). Luyssaert et al. (2007) published the results of different measurements techniques for NEP in eight different biome types at a global scale. In their study, the highest NEP was found in temperate humid evergreen forests. The reason behind high NEP is the fact that biome is most probably due to high carbon storage capacity of the managed forests.

Table 3. Multi regression analysis between NEP and used seven variables

\begin{tabular}{|c|c|c|c|c|c|c|}
\hline \multicolumn{5}{|c|}{ Model Summary } & & \\
\hline Model & $\mathrm{R}$ & R Square & Adjusted R Square & $\begin{array}{l}\text { Std. Error of the } \\
\text { Estimate }\end{array}$ & & \\
\hline 1 & $.268^{\mathrm{a}}$ &, 072 & 018 & 13,894254363 & & \\
\hline \multicolumn{7}{|c|}{ a. Predictors: (Constant), sfcWind (m s-1), pr, rlds (W m-2), rsds (W m-2), CO2 (ppm), huss (kg/kg), tas (K) } \\
\hline \multicolumn{7}{|c|}{ ANOVAิ } \\
\hline Model & & Sum of Squares & df & Mean Square & $\mathrm{F}$ & Sig. \\
\hline \multirow{3}{*}{1} & Regression & 1817,899 & 7 & 259,700 & \multirow[t]{3}{*}{1,345} & $.235^{b}$ \\
\hline & Residual & $23552,13 \pi$ & 122 & 193,050 & & \\
\hline & Total & $25370,03 \oint$ & 129 & & & \\
\hline
\end{tabular}

Net Ecosystem Production 1971-2000

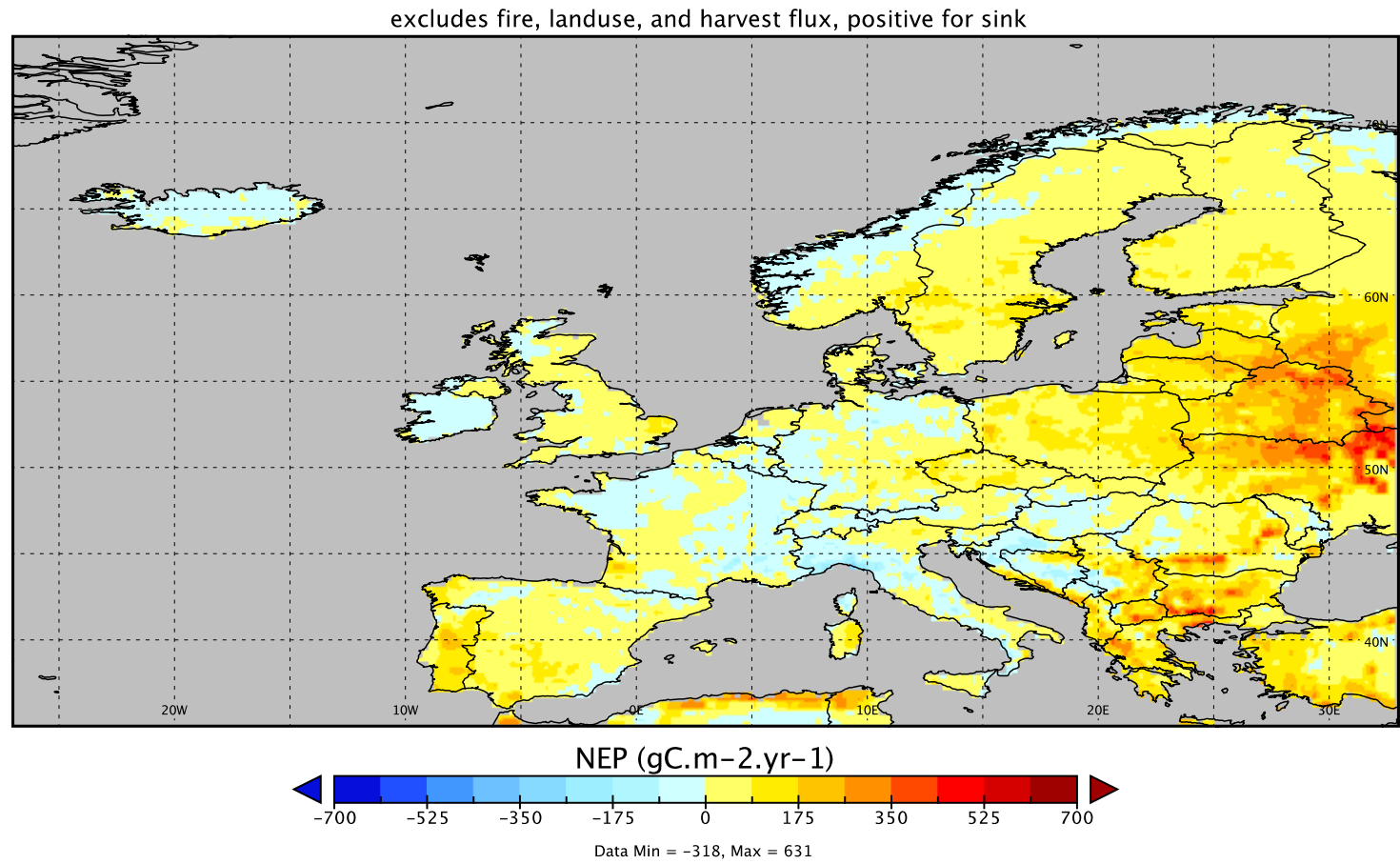

Figure 5. The 30 years (i.e. from 1971 to 2000) average of NEP at pan-European scale

After running the model with climate variables from the CSC-REMO regional climate model (RCM), driven by RCP4.5 emission scenario at a pan-European scale, transient from 2005 to 2100, the result of NEP for 30 years average (i.e. 2071-2100) is shown in Figure 6. In the future projected period, almost all regions and biomes in pan- 
Europe are shown as sink for carbon (Fig. 6). Only a few regions (mountain regions in Norway, in the Alps, and some localities in Spain) are predicted as the source for carbon by the CLM4.5 model under consideration of the RCP4.5 emission scenario (Fig. 6). It is interesting to see that the highest NEP is predicted in the Balkan regions, where mostly temperate broadleafed deciduous forest are noted, and also southern Europe, which shows higher carbon capture capacity than the other regions in Europe during the future period (comparing Figs. 5 and 6 ). Those ecosystems show a wide carbon storage ability in the future.

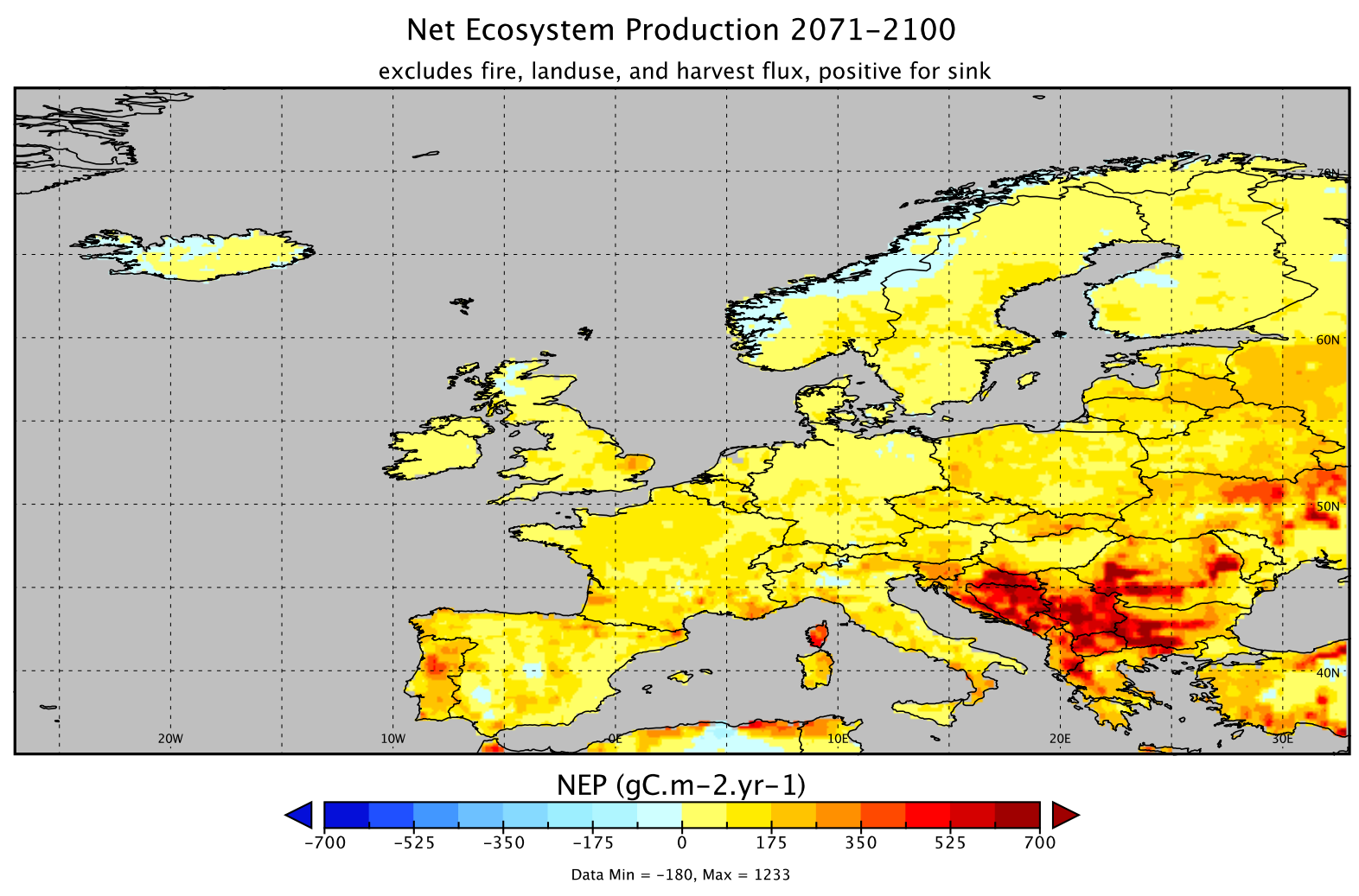

Figure 6. The 30 years (2071-2100) average of NEP at pan-European scale having regard to RCP4.5 emission scenario

The absolute change in NEP, that is, the difference between the past period (19712000) and future projected period (2071-2100) is shown at pan-European level in Figure 7. This remarkable result is the absolute change of NEP in Eastern and Southeastern Europe. Although most of the pan-European regions are predicted as sink regions for carbon in the future projected period, the analysis about absolute change in NEP shows that carbon storage capacity of eastern temperate broadleafed deciduous forests will decrease by about $30 \frac{g C}{m^{2} y r}(\sim 10 \%)$ in the future (Fig. 7). It seems that the ecosystem of this regions could be carbon-saturated under climate change and rising $\mathrm{CO}_{2}$ at the end of the $21^{\text {st }}$ century (Nabuurs et al., 2013; Dirnböck et al., 2020). Those forests currently have the highest carbon storage capacity at a pan-European level. In the past period, the forests in that regions had ca. $178 \frac{P_{g}}{y T}\left(1 \mathrm{Pg}=10^{12} \mathrm{~g}\right)$ carbon storage capacity, however, in the future projected period, it decreases to ca. $166 \mathrm{Pg}$. It shows 
that these forests will store ca. $12 \frac{P g}{y r}$ less carbon than what it stores today. In the whole pan-European domain, the carbon storage capacity of the vegetated areas will increase under climate change at the end of the $21^{\text {st }}$ century. While the carbon storage capacity of the vegetated regions of pan-European studied domain was, on an average, ca. $0.57 \frac{G t}{y r}$ in the past period, it will increase up to $0.91 \frac{G t}{y r}$ in the future period. That shows that the vegetated areas in pan-European domain will store ca. $37 \%$ more carbon at the end of the $21^{\text {st }}$ century.

\section{$\Delta$ Net Ecosystem Production}

excludes fire, landuse, and harvest flux, positive for sink
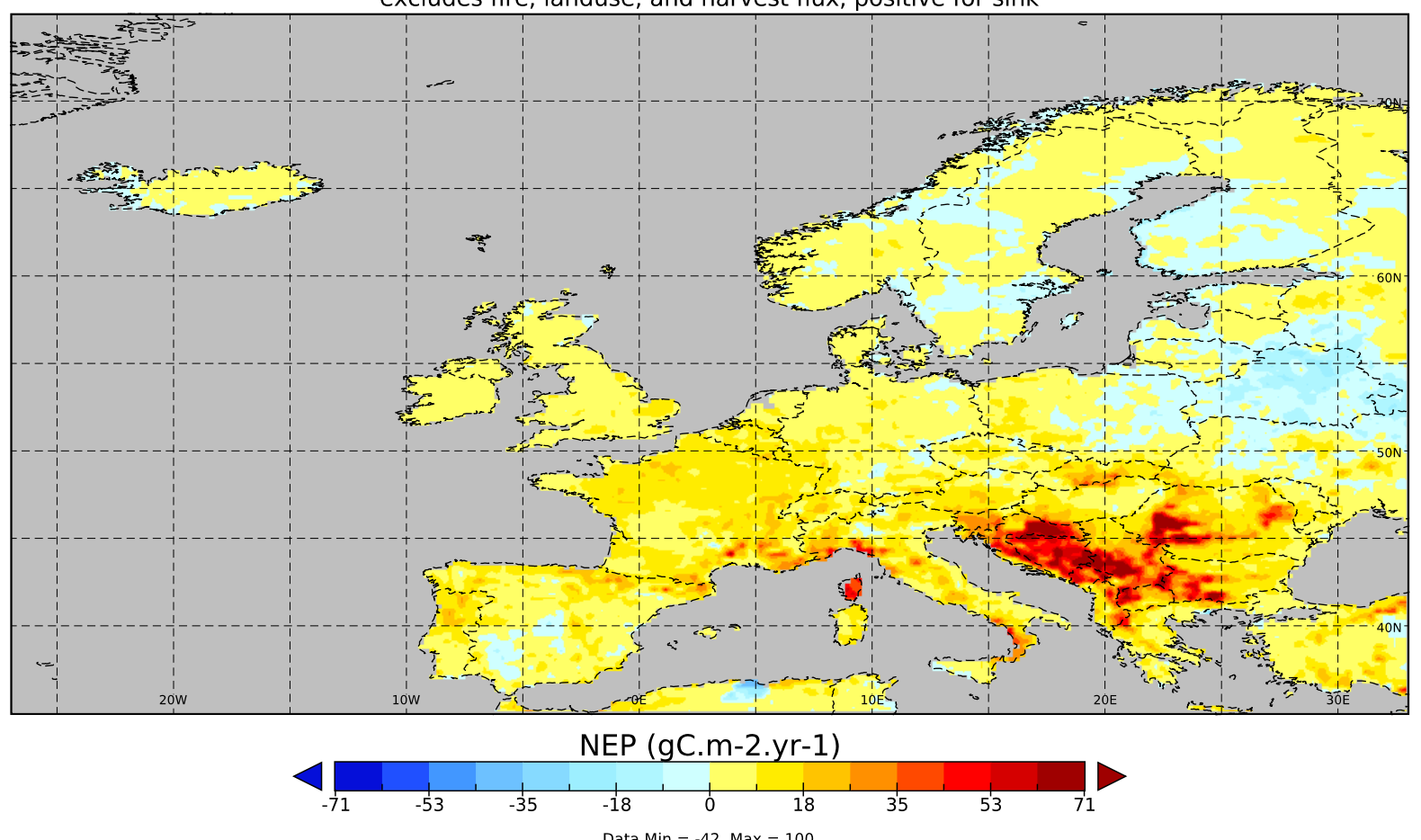

Figure 7. The relative difference between past and future predicted periods (i.e. 1971-2000 and 2071-2100)

\section{Conclusion}

In this study, the main aim was to find the information about the temporal and spatial change in carbon storage capacity of the vegetated areas at a pan-European scale. In general, the pan-European vegetated regions will be considered to be sink areas for carbon. Nearly $1 \mathrm{Gt} \mathrm{C}$ will be stored in the biomass of European vegetation under climate change, by considering the emission scenario RCP4.5 each year. Although the carbon storage capacity of pan-European vegetation will increase in most of the regions, the forests of Eastern Europe show a downward tendency for the accumulation of carbon in the ecosystem. In those regions, the ecosystem shows a trend to lose nearly 12 $\mathrm{Pg} \mathrm{C}$ each year. Furthermore, multiple regression analysis shows no correlation between NEP and used seven variables. The results of this study point to the importance of the investigations of temporal and spatial change in carbon storage capacity of European forests. That will help the researcher to understand the action of forests for being carbon 
source or sink under different climate change scenarios in the future. For the future studies, we are planning to collect more observation data and run the model at global scale to define the carbon sink and source locations.

Acknowledgements. The research has received funding from the scientific and technological research council of Turkey (TUBITAK agreement nr: 2017O394).

\section{REFERENCES}

[1] Arain, M. A., Restrepo-Coupe, N. (2005): Net ecosystem production in a temperate pine plantation in southeastern Canada. - Agricultural and Forest Meteorology 128: 223-241.

[2] Baldocchi, D., Chu, H., Reichstein, M. (2018): Inter-annual variability of net and gross ecosystem carbon fluxes: a review. - Agricultural and Forest Meteorology 249: 520-533.

[3] Campbell, J. L., Sun, O. J., Law, B. E. (2004): Disturbance and net ecosystem production across three climatically distinct forest landscapes. - Global Biogeochemical Cycles 18 GB4017: 1-11.

[4] Cao, M., Ian Woodward, F. (1998): Dynamic responses of terrestrial ecosystem carbon cycling to global climate change. - Nature 393: 249-252.

[5] Chen, Z., Yu, G., Wang, Q. (2020): Effects of climate and forest age on the ecosystem carbon exchange of afforestation. - Journal of Forestry Research 31: 365-374.

[6] Dirnböck, T., Grote, R., Klatt, S., Kobler, J., Schindlbacher, A., Seidl, R., Thom, D., Kiese, R. (2020): Substantial understory contribution to the C sink of a European temperate mountain forest landscape. - Landscape Ecology 35: 483-499.

[7] Erickson, J. E., Peresta, G., Montovan, K. J., Drake, B. G. (2013): Direct and indirect effects of elevated atmospheric $\mathrm{CO}_{2}$ on net ecosystem production in a Chesapeake Bay tidal wetland. - Global Change Biology 19: 3368-3378.

[8] Esser. G., Kattge. J., Sakalli, A. (2011): Feedback of carbon nitrogen cycles enhances carbon sequestration in the terrestrial biosphere. - Global Change Biology 17(2): 819842.

[9] Fernandez-Martinez, M., Sardans, J., Chevallier, F., Ciais, P., Obersteiner, M., Vicca, S., Canadell, J. G., Bastos, A., Friedlingstein, P., Stich, S., Piao, S. L., Janssens, I. A., Penuelas, J. (2019): Global trends in carbon sink and their relationship with $\mathrm{CO}_{2}$ and temperature. - Nature Climate Change 9: 73-79.

[10] IIASA (2014): International Institute for Applied System Analysis. RCP database version 2.0.5. - http://tntcat.iiasa.ac.at/RcpDb (accessed 15 June 2014).

[11] Jacob, D., Petersen, J., Eggert, B., Alias, A., Christensen, O. B., Bouwer, L. M., Braun, A., Colette, A., Deque, M., Georgievski, G., Georgopoulou, E., Gobiet, A., Menut, L., Nikulin, G., Haensler, A., Hempelmann, N., Jones, C. et al. (2013): EURO-CORDEX: new high-resolution climate change projections for European impact research. - Regional Environmental Change 14(2): 563-578.

[12] Jarvis, P. G. (1995): The role of temperate trees and forests in $\mathrm{CO}_{2}$ fixation. - Vegetatio 121(1): 157-174.

[13] Jiang, Z., Lian, Y., Qin, X. (2013): Carbon cycle in the epikarst systems and its ecological effects in South China. - Environmental Earth Sciences 68: 151-158.

[14] Han, P., Lin, X., Zhang, W., Wang, G., Wang, Y. (2019): Projected changes of alpine grassland carbon dynamics in response to climate change and elevated $\mathrm{CO}_{2}$ concentrations under Representative Concentration Pathways (RCP) scenarios. - PLoS ONE 14(7): e0215261.

[15] Hinojo-Hinojo, C., Castellanos, A. E., Huxman, T., Rodriguez, J. C., Vargas, R., RomoLeon, J. R., Biederman, J. A. (2019): Native shrubland and managed buffelgrass savanna 
in drylands: Implications for ecosystem carbon and water fluxes. - Agricultural and Forest Meteorology 268: 269-278.

[16] Koven, C. D., Riley, W. J., Subin, Z. M., Tang, J. Y., Torn, M. S., Collins, W. D., Bonan, G. B., Lawrence, D. M., Swenson, S. C. (2013): The effect of vertically resolved soil biogeochemistry and alternate soil $\mathrm{C}$ and $\mathrm{N}$ models on $\mathrm{C}$ dynamics of CLM4. Biogeosciences 10: 7109-7131.

[17] Law, B. E., Flage, E., Gu, L., Baldocchi, D. D., Bakwin, P., Berbigier, P., Davis, K., Dolman, A. J., Falk, M., Fuentes, J. D., Goldstein, A., Granier, A., Grelle, A., Hollinger, D., Janssens, I. A., Jarvis, P., Jensen, N. O., Katul, G., Mahli, Y., Matteucci, G., Meyers, T., Monson, R., Munger, W., Oechel, W., Olson, R., Pilegaard, K., Paw U. K. T., Thorgeirsson, H., Valentini, R., Verma, S., Vesala, T., Wilson, K., Wofsy, S. (2002): Environmental controls over carbon dioxide and water vapor exchange of terrestrial vegetation. - Agricultural and Forest Meteorology 113: 97-120.

[18] Liu, J., Feng, W., Zhang, Y-Q., Jia, X., Wu, B., Qin, S., Fa, K., Lai, Z. (2015): Abiotic $\mathrm{CO}_{2}$ exchange between soil and atmosphere and its response to temperature. Environmental Earth Sciences 73: 2463-2471.

[19] Lovett, G. M., Cole, J. J., Pace, M. L. (2006): Is net ecosystem production equal to ecosystem carbon accumulation? - Ecosystems 9: 152-155.

[20] Luyssaert, S., Inglima, I., Jung, M., Richardson, A. D., Reichstein, M., Papale, D., Piao, S. L., Schulze, E. D., Wingate, L., Matteucci, G., Aragao, L., Aubinet, M., Beer, C., Bernhofer, C., Black, K. G., Bonal, D., Bonnefond, J. M., Chambers, J., Ciais, P., Cook, B., Davis, K. J., Dolman, A. J., Gielen, B., Goulden, M., Grace, J., Granier, A., Grelle, A., Griffis, T., Grünwald, T., Guidolotti, G. et al. (2007): $\mathrm{CO}_{2}$ balance of boreal, temperate, and tropical forests derived from a global database. - Global Change Biology 13: 2509-2537.

[21] Magnani, F., Mencuccini, M., Borghetti, M., Berbigier, P., Berninger, F., Delzon, S., Grelle, A., Hari, P., Jarvis, P. G., Kolari, P., Kowalski, A. S., Lankreijer, H., Law, B. E., Lindroth, A., Loustau, D., Manca, G., Moncrieff, J. B., Rayment, M., Tedeschi, V., Valentini, R., Grace, J. (2007): The human footprint in the carbon cycle of temperate and boreal forests. - Nature 447: 848-850.

[22] Nabuurs, G-J., Lindner, M., Verkerk, P. J., Gunia, K., Deda, P., Michalak. R., Grassi, G. (2013): First signs of carbon sink saturation in European forest biomass. - Nature Climate Change 3: 792-796.

[23] Nayak, R. K., Patel, N. R., Dadhwal, V. K. (2015): Spatio-temporal variability of net ecosystem productivity over India and its relationships to climatic variables. Environmental Earth Sciences 74: 1743-1753.

[24] Oleson, K., Lawrence, D., Bonan, G., Drewniak, B., Huang, M., Koven, C., Levis, S., Li, F., Riley, W., Subin, Z., Swenson, S., Thornton, P., Bozbiyik, A., Fisher, R., Heald, C., Kluzek, E., Lamarque, J-F., Lawrence, P., Leung, L., Yang, Z-L. (2013): Technical description of version 4.5 of the Community Land Model (CLM). - NCAR Technical Note NCAR/TN-503+STR, National Center for Atmospheric Research, Boulder, CO.

[25] Pan, Y., Birdsey, R. A., Fang, J., Houghton, R., Kauppi, P. E., Kurz, W. A., Phillips, O. L., Shvidenko, A., Lewis, S. L., Canadell, J. G., Ciais, P., Jackson, R. B., Pacala, S. W., McGuire, A. D., Piao, S., Rautiainen, A., Sitch, S., Hayes, D. (2011): A large and persistent carbon sink in the world's forests. - Science 333: 988-992.

[26] Pittau, F., Lumia, G., Heeren, N., Iannaccone, G., Habert, G. (2019): Retrofit as a carbon sink: the carbon storage potentials of the EU housing stock. - Journal of Cleaner Production 214: 365-376.

[27] Potter, C. S., Randerson, J. T., Field, C. B., Matson, P. A., Vitousek, P. M., Mooney, H. A., Klooster, S. A. (1993): Terrestrial ecosystem production: a process model based on global satellite and surface data. - Global Biogeochemical Cycles 7(4): 811-841. 
[28] Randerson, J. T., Chapin, F. S., Harden, J. W., Neff, J. C., Harmon, M. E. (2002): Net ecosystem production: a comprehensive measure of net carbon accumulation by ecosystems. - Ecological Applications 12(4): 937-947.

[29] Seidensticker, L. E., Najjar, R. G., Herrmann, M., Boyer, J. N., Briceno, H. O., Kemp, W. M., Tomaso, D. J. (2019): Seasonal and interannual variability in net ecosystem production of a subtropical coastal lagoon inferred from monthly oxygen surveys. Estuaries and Coasts 42: 455-469.

[30] Schulze, E-D., Beck, E., Buchmann, N., Clements, S., Müller-Hohenstein, K., SchererLorenzen, M. (2019): Biogeochemical fluxes in terrestrial ecosystems. - Plant Ecology 16: 529-577.

[31] Turner. D. P., Ritts. W. D., Law, B. E., Cohen, W. B., Yang, Z., Hudiburg, T., Campbell, J. L., Duane, M. (2007): Scaling net ecosystem production and net biome production over a heterogeneous region in the western United States. - Biogeosciences 4: 597-612.

[32] Wong, G. X., Hirata, R., Hirano, T., Kiew, F., Aeries, E. B., Musin, K. K., Waili, J. W., Lo, K. S., Melling, L. (2020): How do land use practices affect methane emissions from tropical peat ecosystems? - Agricultural and Forest Meteorology 282-283: 107869.

[33] Woodwell, G. M., Whittaker, R. H. (1968): Primary production in terrestrial ecosystems. - Am Zoologist 8: 19-30.

[34] Yang, F., Zhang, Q., Zhou, J., Yue, P., Wang, R., Wang, S. (2019): East Asian summer monsoon substantially affects the inter-annual variation of carbon dioxide exchange in semi-arid grassland ecosystem in Loess Plateau. - Agriculture, Ecosystems \& Environment 272: 218-229. 